\title{
ANTIMICROBIAL ACTIVITY OF VARIOUS PLANTS EXTRACTS AGAINST SOME COMMON PATHOGENIC MICROORGANISM
}

\author{
Sinai Waleed \\ Tropical-Biological Research Unit, College of Science, University of Baghdad.
}

\begin{abstract}
The effects of plants aqueous extracts (Myrtle, Harmal, Henna, Thyme and Fenugreek) against some clinical species of microorganisms were studied. These isolates included: Pseudomonas sp., Klebseilla sp., Escherichia coli, Proteus sp., Staphylococcus aureus and Candida albicans. The susceptibility of these isolates was tested against plants aqueous extracts by the agar well diffusion method. The results showed that the aqueous extract of Myrtle inhibited the growth of all tested microorganisms at concentration 5\%, followed by Harmal when all tested bacteria were inhibited at concentration $10 \%$ except $C$. albicans inhibited at $20 \%$. Compare with Henna when all bacteria were inhibited at concentration $20 \%$ except $C$. albicans was resistant, followed by Thyme which only two bacteria (Klebsiella sp. \& Staphylococcus aureus) were inhibited at $20 \%$ while the remaining microorganism were resistant. On other hand all tested microorganisms were resistant to Fenugreek even at high concentration.
\end{abstract}

\section{Introduction}

Traditionally, plants are used as source of treatment of disease in different parts of the world (1). They are able to produce different compounds that be used to protect themselves against different types of pathogens (2).

Plants are rich in a wide variety of secondary metabolites such as: tannins, terpenoids, alkaloids and flavonoide which have been found in vitro to have antimicrobial properties $(2,3,4)$.

The wide range of current antibiotics available for treatment of bacterial infections, there are still some challenges to be met in microbial chemotherapy. One of the problems is the development of resistance to chemotherapeutic agent due to abuse of these drugs (5).

This study was conducted in order to study the antimicrobial effect of aqueous extracts of Thyme (Thymus vulgaris l.), Myrtle (Myrtus communis), Harmal (Penganum harmala l.), Henna (Lawsonia inermis l.) and Fenugreek (Trigonella foenum-graecum) against six clinical species of microorganisms.

\section{Materials and Methods \\ Tested Microorganisms \\ Isolation and identification}

Samples were collected from urine and burn wound infections, from patients attending Al-Yarmouk Teaching Hospital during the period from $1 / 2 / 2004$ to $1 / 5 / 2004$. All samples were cultured directly on blood agar, MacConkey agar and sabouraud dextrose agar. The cultures were examined after overnight incubation at $25^{\circ} \mathrm{C}-37^{\circ} \mathrm{C}$.

Identification was based on gram stain, culture methods and biochemical tests $(6,7,8)$.

These microorganisms are: Pseudomonas sp., Klebseilla sp., Escherichia coli, Proteus sp., Staphylococcus aureus and Candida albicans.

- Identification of gram negative bacteria was based on the following tests: indole test, TSI test, citrate utilization, urease test, motility test and oxidase test.

- Identification of Staphylococcus aureus was based on the following tests: catalase test, hemolysis test, manitol salt agar, coagulase test.

- Identification of Candida albicans was based on the following tests: germ tube formation, chlamydospore production.

\section{Plants collection}

Five plants (Thyme, Myrtle, Henna, Harmal and Fenugreek) were collected from different localities in Iraq. They were air dried and packed in plastic containers until used as shown in Table (1).

\section{Extracts preparation}

About 50 gm of plant powder mixed with $250 \mathrm{ml}$ of distilled water. After $24 \mathrm{hrs}$, the extracts were filtered through Watmen No.1 and concentrated to dryness and kept in 
labeled dark bottle at $4^{\circ} \mathrm{C}$ until used. Various concentrations were made from aqueous extracts $5 \%, 10 \%$ and $20 \%$ in order to study the effect of these concentrations on different microorganisms.

\section{Agar well diffusion method}

The antimicrobial activity was determined by the well diffusion method (9). Wells were made in Mueller Hinton agar for bacteria and sabouraud dextrose agar for $C$. albicans. Plates were seeded with $0.1 \mathrm{ml}$ of $10^{8} \mathrm{CFU} / \mathrm{ml}$ of bacteria, $10^{6} \mathrm{CFU} / \mathrm{ml}$ of $C$. albicans. $(0.1) \mathrm{ml}$ of plant extracts were added to the wells. Triplicates of each concentration for each microorganism species were prepared. The inoculated plates were incubated at $37^{\circ} \mathrm{C}$ for 24 hours for bacteria and $25^{\circ} \mathrm{C}$ for $24-48$ hours for $C$. albicans. The diameter of the inhibition zones were measured for each plate. The standard Tetracycline disk (30 mcg) was used as a control (10).

\section{Statistical analysis}

Duncan's test was used in the analysis of results.

\section{Results and Discussion}

In this study the extracts of the following medicinal plant (Myrtle, Harmal, Henna, Thyme and Fenugreek), were tested for their in vitro antibacterial activity against six isolates of microorganisms (Pseudomonas sp., Klebseilla sp., Proteus sp., E. coli, Staphylococcus aureus and Candida albicans) isolated from urinary tract and burn wound infections as shown in Table (2).

The results showed that the aqueous extract of Myrtle inhibits the growth of all tested microorganisms at concentration 5\% and the best effect was on growth of Proteus $s p$. inhibition zone diameter $30 \mathrm{~mm}$., followed by Harmal when all tested bacteria were inhibited at concentration $10 \%$ except C. albicans inhibited at $20 \%$, the best effect was on growth of Proteus sp. and Klebseilla $s p$. inhibition zone diameter $30 \mathrm{~mm}$. In regard to Henna, all bacteria were inhibited at concentration $20 \%$ except C. albicans was resistant, the best effect was on growth of Klebseilla sp. inhibition zone diameter $25 \mathrm{~mm}$. Followed by Thyme which only two bacteria (Klebsiella sp. \& Staphylococcus aureus) were inhibited at $20 \%$, the best effect of inhibition zone diameter on them was $10 \mathrm{~mm}$. while the remaining microorganisms were resistant. On other hand all tested microorganisms were resistance to Fenugreek even at high concentration.

The zone of inhibition produced by aqueous extracts of Myrtle, Harmal and henna were higher than that produced by Tetracycline.

According to Duncan's test showed that plants extracts have significant difference $(\mathrm{p} \leq 0.05)$ between them.

Plant extracts have been used for many thousands of years, in food preservation, pharmaceutical, alternative medicine and natural therapies $(10,11,12)$.

Myrtle is strongly antibacterial and antifungal herb. This effect may be due to its component which includes:

myrtucommulone-B, myrtucommuloneA, Saponins, phenols, steroids, gallic acid, ellagic acid, acetic acid, citric acid, carvacrol and tannin, They can be toxic to bacteria and yeasts $(13,14)$. Several studies $(15,16)$ have shown that Myrtle have strong and consistent inhibitory effects against various pathogens.

The antimicrobial activity of Harmal extract may be due to presence of harmaline, harmine and harmalol (17); these compounds had antibacterial and antiparasitic activities $(18,19)$. In addition, the Henna extract also showed good antimicrobial effects but high concentrations were required to kill these bacteria except $C$. albicans was resistant, this finding is agreement with Muhammad et al. (20) which found that water extract has no activity against the $C$. albicans.

Whereas Thyme and Fenugreek show less or no effect frequently on tested microorganisms, this may be the plant compounds are not dissolved in aqueous solutions (21).

The present study showed that Myrtle, Harmal and Henna extracts were capable of inhibiting the growth of microorganisms that are involved in causing urinary and burn wound infections. 
Table (1)

Plants uses in the study, their names and uses part.

\begin{tabular}{|c|c|c|c|c|}
\hline $\begin{array}{c}\text { Common } \\
\text { name }\end{array}$ & $\begin{array}{c}\text { Arabic } \\
\text { name }\end{array}$ & Scientific name & Family & Uses part \\
\hline Myrtle & 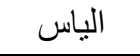 & Myrtus communis $L$. & Myrtaceae & leaves \\
\hline Thyme & 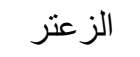 & Thymus vulgaris $L$. & Lamiaceae & leaves \\
\hline Henna & 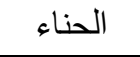 & Lawsonia inermis $L$. & Lythraceae & leaves \\
\hline Fenugreek & الحلبة & Trigonella foenum-graecum & Fabaceae & seeds \\
\hline Harmal & 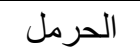 & Peganum harmala & Zygophyllaceae & seeds \\
\hline
\end{tabular}

\section{Table (2)}

Diameter of inhibition zones caused by five crude plant extracts at various concentrations on some microorganisms.

\begin{tabular}{|c|c|c|c|c|c|c|c|c|}
\hline \multirow[b]{2}{*}{ Plants } & \multirow[b]{2}{*}{$\begin{array}{c}\text { Conc. of } \\
\text { plants } \\
\text { extracts }\end{array}$} & \multicolumn{6}{|c|}{$\begin{array}{l}\text { Diameter of inhibition zone }(\mathrm{mm}) \text { of } \\
\text { microorganisms }\end{array}$} & \multirow[b]{2}{*}{$\begin{array}{l}\text { Inhibition zone } \\
(\text { Mean } \pm \text { S. E)* }\end{array}$} \\
\hline & & 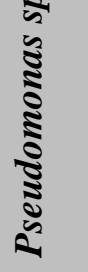 & $\begin{array}{l}\dot{1} \\
5 \\
\vdots \\
\vdots \\
\vdots \\
\vdots \\
\vdots\end{array}$ & 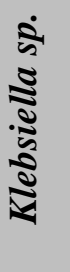 & i⿱ & 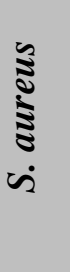 & 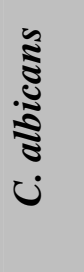 & \\
\hline \multirow{3}{*}{ Thyme } & $5 \%$ & - & - & - & - & - & - & $-{ }^{a}$ \\
\hline & $10 \%$ & - & - & - & - & - & - & $-{ }^{\mathrm{a}}$ \\
\hline & $20 \%$ & 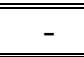 & - & 10 & - & 10 & - & $3.3 \pm 2.1^{\mathrm{ab}}$ \\
\hline \multirow{3}{*}{ Henna } & $5 \%$ & - & - & - & - & - & - & $-^{\mathrm{a}}$ \\
\hline & $10 \%$ & - & - & - & - & - & - & $-{ }^{\mathrm{a}}$ \\
\hline & $20 \%$ & 20 & 18 & 25 & 15 & 20 & - & $16.3 \pm 3.5^{\mathrm{cd}}$ \\
\hline \multirow{3}{*}{ Myrtle } & $5 \%$ & 21 & 18 & 20 & 20 & 22 & 20 & $20.2 \pm 0.5^{\mathrm{de}}$ \\
\hline & $10 \%$ & 23 & 20 & 25 & 23 & 24 & 23 & $23.0 \pm 0.7^{\mathrm{et}}$ \\
\hline & $20 \%$ & 27 & 30 & 27 & 25 & 26 & 27 & $27.0 \pm 0.7^{\mathrm{t}}$ \\
\hline \multirow{3}{*}{ Harmal } & $5 \%$ & - & 20 & 10 & 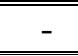 & 10 & - & $6.7 \pm 3.3^{b}$ \\
\hline & $10 \%$ & 19 & 25 & 15 & 14 & 15 & 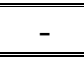 & $14.7 \pm 3.4^{\mathrm{c}}$ \\
\hline & $20 \%$ & 22 & 30 & 30 & 26 & 21 & 10 & $23.2 \pm 3.1^{\mathrm{eft}}$ \\
\hline \multirow{3}{*}{ Fenugreek } & $5 \%$ & 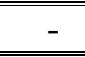 & - & - & 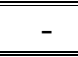 & 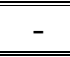 & - & $-{ }^{-a}$ \\
\hline & $10 \%$ & - & - & - & - & - & - & $-{ }^{\mathrm{a}}$ \\
\hline & $20 \%$ & - & - & - & - & - & - & $-{ }^{\mathrm{a}}$ \\
\hline Tetracycline & $30 \mathrm{mcg}$ & 9 & $\overline{10}$ & $\overline{10}$ & 13 & 20 & $\overline{\text { NT }}$ & $12.4 \pm 2.0^{c}$ \\
\hline
\end{tabular}

(-) No inhibition zone, (NT) not tested, (*) Different letters: significant difference $(P \leq 0.05)$ between means. 


\section{References}

[1] K. Hostettmann, A. Marston, K. Ndojoko and J. Wolfender, "The potential of Africa plants as source of drug". In: curr. organic chem., Vol. 4, 2000, pp. 973 - 1010.

[2] O.O. Aboaba, S.I. Smith and F.O. Olude, "Antibacterial effect of Edible plant extract on Escherichia coli: O157: H7", Pakistan J. Nutri., Vol. 5, No. 4, 2006, pp.325 - 327.

[3] M.M. Cowam, "Plant products as antimicrobial agents", Clin. Microbiol. Revi. Vol. 12, 1999, pp. 564 - 582.

[4] T. G. Emori and P.P. Gaynes "An over view of nosocomial infections, including the role of microbiology laboratory", Clin. Microbiol. Revi., Vol. 6, 1993, pp.428-442.

[5] F. A. Orrett and S. M. Shurland, "Prevalence of bacterial pathogens and susceptibility patterns from clinical sources in Trinidad", West Ind. Med. J., Vol. 9, No.3, 2000, pp. 205 - 209.

[6] S. Gupte, " The short textbook of medical microbiology", Jay Pee Broth. Del., 1982, pp. 330.

[7] J. G. Holt, N. R. Krieg, P. H. A. Sneath, J. T. Staley, and S.T. Williams, "Bergey's manual of determinative bacteriology", $9^{\text {th }}$ edn. William. Wilk. Maryl, 1994, pp. $285-289$.

[8] G. S. Kobayashi and D. Pappagianis, "The Mycoses" In: Gradwohl's clinical laboratory methods and diagnosis. Edited by Sonnenwirth A.C. and Jaratt L. $8^{\text {th }}$ ed., The C.V. Mosby Company. St. Louis. Toronto. London, 1980, pp. 2211-2239.

[9] National Committee for Clinical Laboratory Standards (NCCLS), "Performance standards for antimicrobial disk susceptibility tests", NCCLS, Pennsylvania, USA, 1993, M2 - A5.

[10] B. Abu- shanab, G. Adwan, D. Abusafiya, K. Adwan, and M. Abu- shanab, "Antibacterial activity of Rhus coriaria $l$. extracts growing in Palestine". J. Islamic Univ. Gaza, Vol. 13, No. 2, 2005, pp. $147-153$.

[11] V. K. Saxena, R. N. Sharma," Antimicrobial activity of the essential oil of Lantana aculeata", Fitoterapia, Vol. 70, 1999, pp. 67 - 70.
[12] I. Ahmad, and A. Z. Beg, "Antimicrobial and phytochemical studies on 45 Indian medicinal plants against multidrug resistant human pathogens". J Ethnopharmacol., Vol. 74, 2001, pp.113-123.

[13] G. A. El- Hossary, and S. H. Tadross, "Phytochemical study of leaves of Myrtus communis L. grown in Egypt", Bull. Fac. pharm. Cairo Univ., Vol. 227, 1989, pp. $101-103$.

[14] A. Rotstein, A. Lifshitz, and Y. Kashman, "Isolation and antibacterial activity of acylphloroglucinols from Myrtus communis", Antimicrobial agents and chemotherapy, Vol. 6, No. 5, 1974, pp. $539-542$.

[15] A. A. T. Al-Najim, " The antibacterial effect of some medicinal plant extracts on bacteria isolated from wounds and burns" A thesis of higher diploma in Genetic Engineering and biotechnology-University of Baghdad, 2004.

[16] A. Abdul Hussein and S. AL-Janabi, "In vitro effects of Myrtus communis L. extract on the Tinea versicolor microorganisms", J. Karbala univ., Vol. 2, No.9, 2005, pp. 214-217.

[17] S. Kamel, L. Ibrahim, A. Afifi and S. Hamza "Major alkaloidal constituents of the Egyptian plant. Peganum harmala". UARJ, Vet. Sci., Vol.7, 1970, pp. 71 - 86.

[18] A. Abdul Hussein and S. AL-Janabi, "Antimicrobial activity of Peganum harmala l. crude extract", J. Karbala univ., Vol. 1, No. 2, 2003, pp. 277 - 283.

[19] A. Astulla, K. Zaima, Y. Matsuno, Y. Hirasawa, W. Ekasari, A. Widyawaruyanti, N. C. Zaini, and $\mathrm{H}$. Morita, "Alkaloids from the seeds of Peganum harmala showing antiplasmodial and vasorelaxant activities", J. Nat. Med., Vol. 62, 2008, pp. 470 - 472.

[20] H. S. Muhammad and S. Muhammad, " The use of Lawsonia inermis linn. (Henna) in the management of burn wound infections", African J. Biotechnol, Vol. 4, No. 9, 2005, pp. 934 - 937. 
[21] I. E. AL- Saimary, and S. S. Baker, "Extraction of antibacterial agents from $\mathrm{H}$ Lasocarpium Fisch and Mey (Boraginaceae)" $1^{\text {st }}$ conf. of the Nat Board for Biotechnical. Res. Baghdad, 2001.

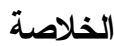

تم در اسة تأثثر المستخلص المائي للنباتــات الثاليــة:

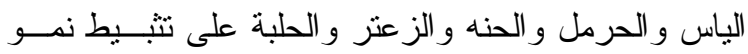

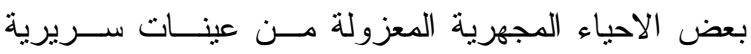

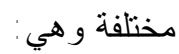

Pseudomonas sp., Klebseilla sp., Escherichia coli, Proteus sp., Staphylococcus aureus, Candida albicans

أختبرت حساسية تلك العزلات تجاه المستخلصات النباتية

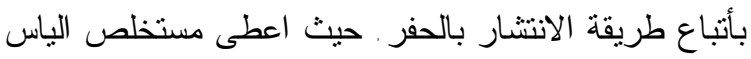

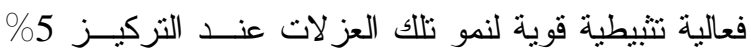

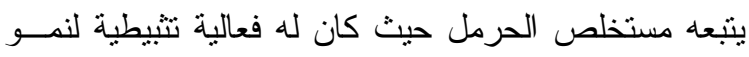

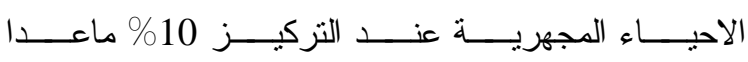

Candida albicans

مستخلص الحنه كانت لها فعالية تثيطية عند التركيز 20\%

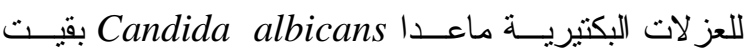

مقاومة لمستخلص الحنه. اما الزعتر فكانــت لــهـ فعاليــة

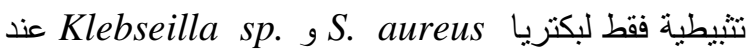

التركيز 20\%، في حين لم يلاحظ اي فعالية تنبيطية للاحياء

المجهرية تجاه مستخلص الحلبه المائي. 